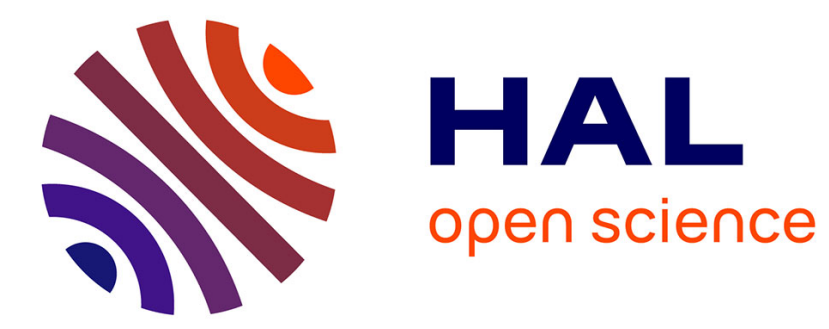

\title{
PREPARATION OF SiC FILMS BY PHOTOCHEMICAL VAPOUR DEPOSITION USING
} A D2 LAMP

S. Motojima, S. Mano

\section{- To cite this version:}

S. Motojima, S. Mano. PREPARATION OF SiC FILMS BY PHOTOCHEMICAL VAPOUR DEPOSITION USING A D2 LAMP. Journal de Physique IV Proceedings, 1991, 02 (C2), pp.C2-365-C2-371. 10.1051/jp4:1991244 . jpa-00249834

\section{HAL Id: jpa-00249834 \\ https://hal.science/jpa-00249834}

Submitted on 1 Jan 1991

HAL is a multi-disciplinary open access archive for the deposit and dissemination of scientific research documents, whether they are published or not. The documents may come from teaching and research institutions in France or abroad, or from public or private research centers.
L'archive ouverte pluridisciplinaire $\mathbf{H A L}$, est destinée au dépôt et à la diffusion de documents scientifiques de niveau recherche, publiés ou non, émanant des établissements d'enseignement et de recherche français ou étrangers, des laboratoires publics ou privés. 


\title{
PREPARATION OF SIC FILMS BY PHOTOCHEMICAL VAPOUR DEPOSITION USING A $D_{2}$ LAMP
}

\author{
S. MOTOJIMA and S. MANO \\ Department of Applied Chemistry, Faculty of Engineering, Gifu \\ University, Gifu 501-11, Japan
}

\begin{abstract}
SiC films have been prepared by photochemical vapour deposition using a $D_{2}$ lamp from a gas mixture of $\mathrm{CH}_{3} \mathrm{SiCl}_{3}+\mathrm{H}_{2}+\mathrm{Ar}$ on a graphite plate. The deposition temperature of the SiC films of a single phase was lowered by irradiation with a $D_{2} 1$ amp by $50^{\circ} \mathrm{C}$ as compared to that without irradiation. Furthermore, the deposition rate was increased with irradiation by $1.2-2.8$ times as compared to that without irradiation.
\end{abstract}

\section{1.- Introduction}

Chemical vapour deposition (CVD) is a very important process for obtaining adherent protective coatings against oxidation, corrosion or abrasion, electrical conducting or insulating films, optical films, diffusion barriers, etc. However, the CVD process has many significant shortcomings, such as a limited number of materials for substrates or apparatus, degradation of the strength of the substrate, grain growth, etc. These shortcomings are main1y due to high-temperature processing. Accordingly, many low-temperature processes such as plasma CVD, organometallic CVD, photo CVD, catalytic CVD (1) are now being actively investigated to overcome these shortcomings. These low-temperature CVD processes are mainly used in semiconductor technology, but rarely used in the engineering fields. Preparation of the films of $\mathrm{Si}(2-4), \mathrm{SiO}_{2}(5,6), \mathrm{Si}_{3} \mathrm{~N}_{1}(6,7), \mathrm{A} 1 \mathrm{~N}(8), \mathrm{TiB}_{2}(9)$ etc. has been demonstrated using photo-ctD with a low-pressure Hg lamp, laser or $D_{2}$ lamp. and TiB (12), we have obtained thin films of TiC (10), TiN and $\mathrm{TiB}_{2}$ (12) on stainless steels or graphite plates by photo-CVD processising a $D_{2}$ lamp. We have found that the deposition temperature of these films were lowered by irradiation with the $\mathrm{D}_{2}$ lamp by $50-150^{\circ} \mathrm{C}$ as compared to that without irradiation. Furthermore, we have found that the deposition rates were increased by $35-300 \%$ with irradiation.

In this work, we have obtained the SiC films on graphite substrates by a photo-CVD process using a $D_{2} 1$ amp from a gas mixture of methyltrichlorosilane and hydrogen. The effects of irradiation by the $D_{2}$ lamp on the deposition temperature and deposition rate of the SIC films of a single phase were examined in some detail. 


\section{2. -Experimental procedure}

Experimental apparatus used in this work is schematiçally shown in Fig.1. The substrate (graphite plate, $12 \times 18 \times 1 \mathrm{~mm}^{3}$ ) was polished using emery paper (No. 800), degreased ultrasonically, dried, and set verticaliy in the horizontal reaction tube (quartz, $24 \mathrm{~mm}$ i.d. x $300 \mathrm{~mm}$ long). Vacuum ultraviolet light ( $200 \mathrm{~nm})$ from a $D_{2}$ lamp (Hamamatsu Photonics, L1314, $150 \mathrm{~W}$ ) was directed through a window of a synthetic quartz glass ( $1 \mathrm{~mm}$ thick) onto the substrate. The distance from the $D_{2}$ lamp to the substrate was fixed at $130 \mathrm{~mm}$. Methyltrichlorosilane (MTS) saturated in the hydrogen carrier gas using a circulation-type saturater and introduced into the reaction zone.

\section{3.-Results and Discussion}

X-ray diffraction patterns of the surface of the deposits obtained at various reaction temperatures with and without irradiation by the $D_{2}$ lamp are shown in Fig.2. It can be seen that, without irradiation by the $D_{2}$ lamp, free $S i$ was codeposited with SiC phase in a temperature range of $1000-1050^{\circ} \mathrm{C}$, and that the SiC films of a single phase were obtained at a temperature as high as $1100^{\circ} \mathrm{C}$. On the other hand, it can be seen that, with irradiation by the $\mathrm{D}_{2}$ lamp, SiC films of a single phase without codeposition of free Si were obtained at a temperature as 10 w as $1050^{\circ} \mathrm{C}$. This temperature is $50^{\circ} \mathrm{C}$ lower than that without irradiation. Similar lowering of the deposition temperature with irradiation by the $D_{2}$ lamp has been reported for the deposition of TiN films from a gas mixture of $\mathrm{TiCl}_{4}-\mathrm{NH}_{3}-\mathrm{H}_{2}-\mathrm{Ar}$ (11).

The effect of the reaction temperature on the weight gain of the deposits for 30 min reaction time is shown in Fig.3, in which the open circle and open triangle denote the deposition of the SiC films of a single phase, while solid ones denote that of a mixed phase of $\mathrm{SiC}$ and a free Si. The weight gain of the deposits with irradiation by the $\mathrm{D}_{2}$ lamp was always larger than that without irradiation, and was about 2.2 times at $1000^{\circ} \mathrm{C}$ and $1.2-1.3$ times at $1050-1100^{\circ} \mathrm{C}$. It is important to know whether or not this weight increase with irradiation by the $D_{2}$ lamp was affected by the increased deposition rate of free carbon. It was reported that deposition rate of the TiC films from a gas mixture of $\mathrm{TiCl}_{4}+\mathrm{CH}_{4}$ (or $\left.\mathrm{CCl}_{4}\right)+\mathrm{H}_{2}+\mathrm{Ar}$ was increased by irradiation from a $\mathrm{D}_{2}$ lamp by 1.5-2.2 times as compared to that without irradiation, and that deposition of a free carbon was not observed with irradiation (10). Accordingly, it may be considered that the increase in the weight of the deposits with irradiation was effected not by the increased deposition of free carbon but by deposition of a SiC single phase.

X-ray diffraction profiles of the deposits obtained at various gas flow rates of MTS are shown in Fig.4, in which the reaction temperature was fixed at $1050^{\circ} \mathrm{C}$. Without irradiation by the $\mathrm{D}_{2}$ lamp, the mixed phase of $\mathrm{SiC}$ and free $\mathrm{Si}$ was always deposited at all gas flow rates of MTS used in this work. On the other hand, with irradiation by the $D_{2}$ lamp, the SiC films of a single phase were always deposited. At a reaction temperature of $1100^{\circ} \mathrm{C}$, 
the SiC films of a single phase were deposited with and without irradiation at all gas flow rates. That is, an irradiation effect of the $\mathrm{D}_{2}$ lamp on the deposition of the SiC films of a single phase was observed at a relatively $10 \mathrm{w}$ temperature of $1050^{\circ} \mathrm{C}$.

The effect of the gas flow rate of MTS on the weight gain of the deposits is shown in Figs.5 and 6 , in which reaction time was fixed at 30 min. It can be seen that the weight gain with irradiation by the $D_{2}$ lamp was increased by increasing the gas flow rate of MTS and was always $1.3-1.6$ times as compared to that without irradiation at temperatures of $1050^{\circ} \mathrm{C}$ and $1100^{\circ} \mathrm{C}$.

The effect of reaction time on the weight gain of the deposits is shown in Fig.7, in which reaction temperature was fixed at $1100^{\circ} \mathrm{C}$. The weight gain with irradiation was always larger than that without irradiation, and was 2.5-2.8 times as compared to that without irradiation at an initial deposition stage of 10-20 min reaction time. This result suggests that irradiation by the $D_{2}$ lamp accelerates the formation of nuclei of a SiC phase especially at the initial stage of deposition. A similar effect of accelerated formation of nuclei was observed for $\mathrm{TiB}_{2}$ films obtained from a gas mixture of $\mathrm{TiCl}_{4}+\mathrm{BCl}_{3}+\mathrm{H}_{2}+\mathrm{Ar}$ (12).

Vacuum ultraviolet light ( $200 \mathrm{~nm}$ ) was directed vertically onto the substrate through a stream of a source gas $\left(M T S+H_{2}\right)$ as shown in Fig.1. Accordingly, the following activated processes may be expected. 1) A source gas (MTS) in a vapour phase is activated by irradiation with the $D_{2}$ lamp to form activated molecules, radicals, fragments, etc. 2) $\mathrm{Si}^{2}$ species, which are formed by the decomposition of MTS and adsorbed on the surface of the substrate are activated, and these activated $\mathrm{Si}$ species readily react with carbon species to form SiC species at relatively low temperature. Accordingly, deposition of free carbon may be suppressed. 3) Molecules or fragments adsorbed on the surface of the substrate are activated, and the surface reaction is accelerated. Accordingly, supersaturation on the surface of the substrate is increased to form many nuclei. 4) Some surface energy is added on the surface of the substrate to activate the nucleation of a SiC phase. It may be suggested that the lowering of the deposition temperature of the SiC films of a single phase is mainly effected by the irradiation effects of 1 ) and 2), and the increasing of the deposition rate by the effects of 3 ) and 4).

\section{4.- Conclusions}

SiC films have been prepared by photo CVD using a $D_{2}$ lamp from a gas mixture of $\mathrm{CH}_{3} \mathrm{SiCl}_{3}+\mathrm{H}_{2}+\mathrm{Ar}$ on a graphite plate. The deposition temperature of the SiC films of a single phase could be lowered by irradiation from a $D_{2} 1$ amp by $50^{\circ} \mathrm{C}$ as compared to that without irradiation. Furthermore, the deposition rate could be increased by 1.2-2.8 times as compared to that without irradiation. 


\section{5. - References}

1) H. Matsumura, Proc. 11th Int. Conf, on CVD (1990, Seattle), p. 173.

2) K. Kumata, U. Itoh, Y. Toyoshima, H. Anzai, and A. Matsuda, App1. Phys. Lett., 48, $1380(1986)$.

3) S. Nishida, T. Shiimoto, A. Tamada, and S. Karasawa, Appl. Phys. Lett., 49, 79(1986).

4) N. Matsukura and Y. Machii, Appl. Phys. Lett., 48, 544(1986).

5) M. Okuyama, Y. Toyoda, and Y. Hamakawa, Jpn. J. App1. Phys., 23, L97 (1984).

6) P. Dimitriou and A. Scavennec, Vide Couches Minces, 40, 335(1985).

7) K. Tamagawa, T. Hayashi, and S. Komiya, Jpn. J. App1. Phys., 25, L728(1986).

8) Xim Li and T. L. Tansley, J. App1. Phys., 68, 5369(1990).

9) J. Elders, D. Bebelaar and J. D. W. van Voorst, Preprint E-MRS, 1990 .

10) S. Motojima and H. Mizutani, Thin Solid Films, 186, LI7(1990).

11) S. Motojima and H. Mizutani, Appl. Phys. Iett., 54, $1104(1989)$.

12) S. Motojima and H. Mizutani, Appl. Phys. 1ett., 56, 916(1990).

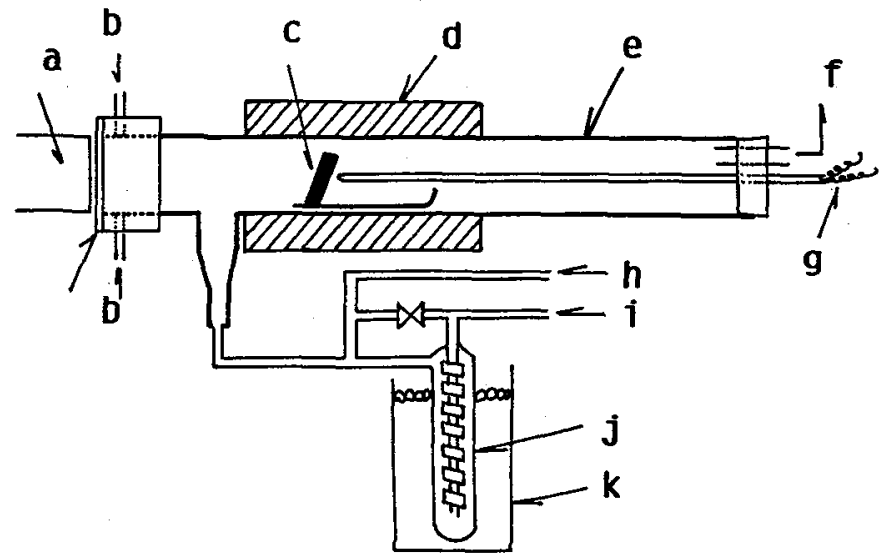

Fig.1. Schematic of the apparatus.

a) $\mathrm{D}_{2}$ lamp, b) $\mathrm{H}_{2}$ or Ar, c) substrate (graphite plate), d) electric furnace, e) reaction tube (quartz), f) gas outlet, g) $\mathrm{CA}$ thermocouple, h) Ar, i) $\mathrm{H}_{2}$, j) saturater of $\mathrm{CH}_{3} \mathrm{SiCl}_{3}, \mathrm{k}$ ) oil bath. 


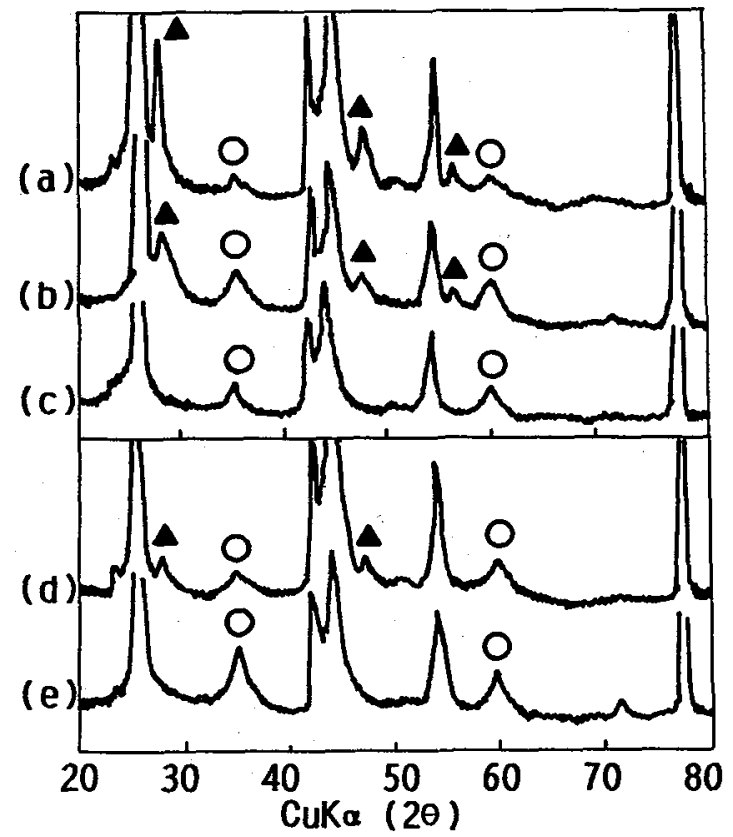

Fig.2. X-ray diffraction patterns of the surface of the deposits (Effect of reaction temperature).

(a)-(c): Without irradiation by a $\mathrm{D}_{2} 1 \mathrm{amp},(\mathrm{d})-(\mathrm{e})$ : with irradiation. Reaction temperature: (a) $1000^{\circ} \mathrm{C}$, (b) $1050^{\circ} \mathrm{C}$, (c) $1100^{\circ} \mathrm{C}$, (d) $1000^{\circ} \mathrm{C}$, (e) $1050^{\circ} \mathrm{C} . \mathrm{CH}_{3} \mathrm{SiCl}_{3}$ gas flow

$\mathrm{rate}=0.16 \mathrm{cc} / \mathrm{s}, \mathrm{H}$, flow rate $=2.0 \mathrm{cc} / \mathrm{s}, 3 \mathrm{Ar}$ flow rate $=3.0 \mathrm{cc} / \mathrm{s}$.

(O): $\beta-S i C,(\boldsymbol{A})$ : Si. Other peaks denote the graphite substrates.

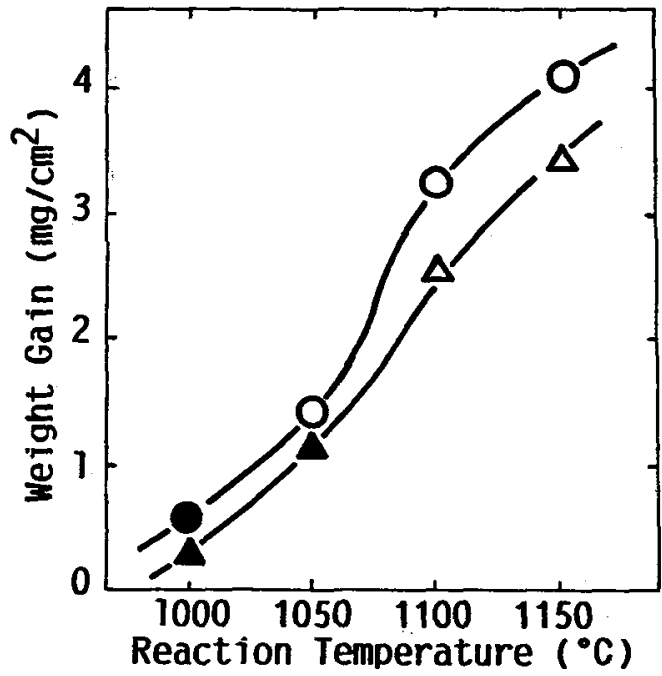

Fig.3. Effect of reaction temperature on the weight gain of the deposits.

$\mathrm{CH}_{3} \mathrm{SiCl}_{3}$ gas flow rate=0.16 cc/s. Reaction time=30 min. ( $\triangle$ ) and (A): Without irradiation by a $D_{2} l$ amp, (O) and (O): with irradiation. (O) and $(\boldsymbol{\Delta}): \beta-\mathrm{SiC}^{2} \mathrm{Si},(\mathrm{O})$ and $(\triangle): \beta-\mathrm{SiC}$ single phase. 


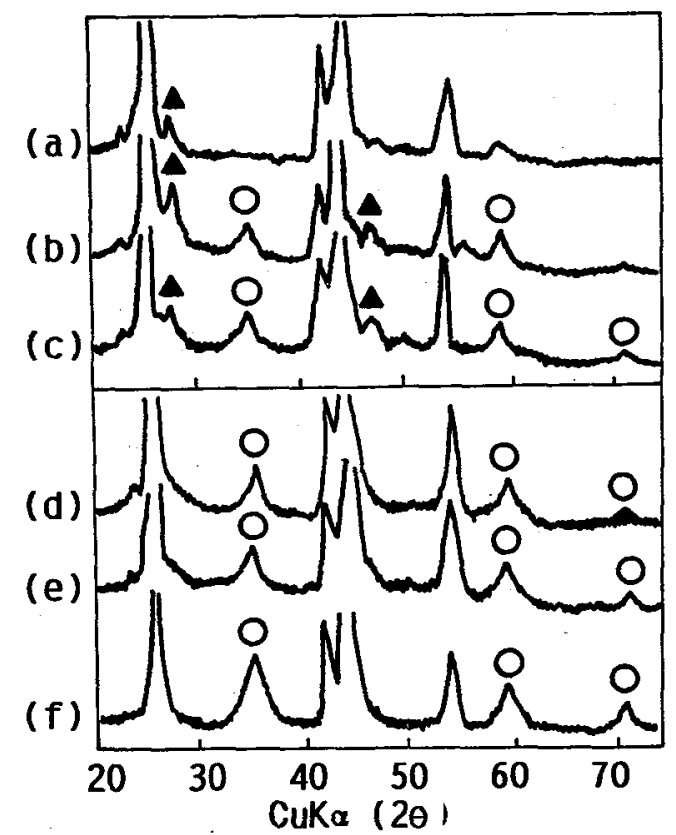

Fig.4. X-ray diffraction patterns of the surface of the deposits (Effect of gas flow rate of $\mathrm{CH}_{3} \mathrm{SiCl}_{3}$ ).

Reaction temperature: $1050^{\circ} \mathrm{C} . \mathrm{CH}_{3} \mathrm{SiCl}_{3}$ gas flow rate $=(\mathrm{a}) .0 .08 \mathrm{cc} / \mathrm{s}$, (b) $0.16 \mathrm{cc} / \mathrm{s}$, (c) $0.32 \mathrm{cc} / \mathrm{s}$, (d) $0.08 \mathrm{cc} / \mathrm{s}$, (e) $0.16 \mathrm{cc} / \mathrm{s}$,

(f) $0.32 \mathrm{cc} / \mathrm{s}$. (a) - (c): Without irradiation by a $\mathrm{D}_{2}$ lamp, (d) (f): with irradiation. (O): $\beta-S i C,(\boldsymbol{A})$ : Si. Other peaks denote the graphite substrate.

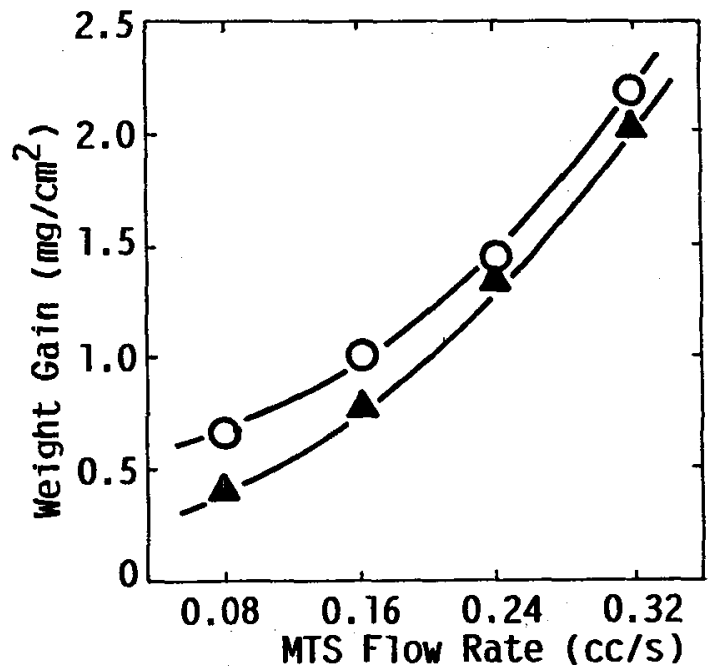

Fig.5. Effect of gas flow rate of $\mathrm{CH}_{3} \mathrm{SiCl}_{3}$ on the weight gain of the deposits.

Reaction temperature $=1050^{\circ} \mathrm{C}$, reaction time $=30 \mathrm{~min}$. (A): Without irradiation by a $D_{2}$ lamp, (O): with irradiation. (A): $\beta-S i C+S i$, (O): $\beta$-SiC single phase. 


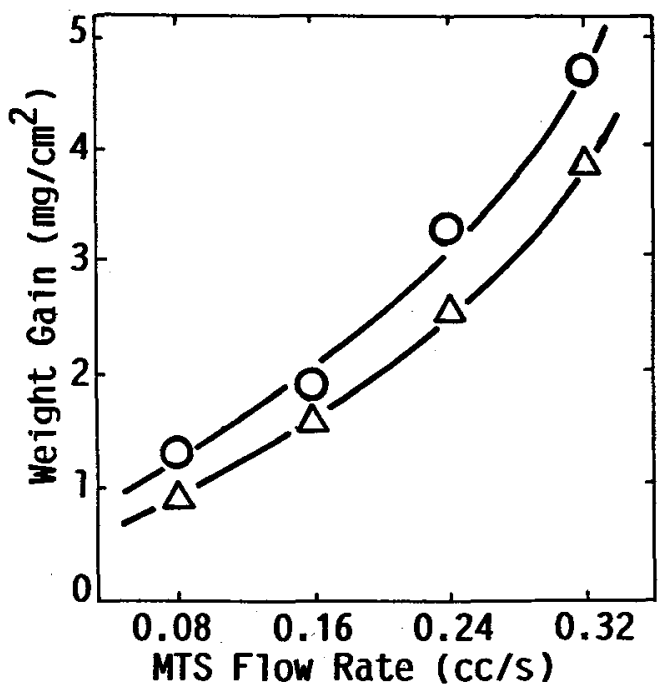

Fig.6. Effect of gas flow rate of $\mathrm{CH}_{3} \mathrm{SiCl}_{3}$ on the weight gain of the deposits.

Reaction temperature $=1100^{\circ} \mathrm{C}$, reaction time $=30$ min. $(\triangle)$ : Without irradiation by a $D_{2}$ lamp, (O): with irradiation. (O) and $(\Delta)$ : $\beta$-SiC single phase?

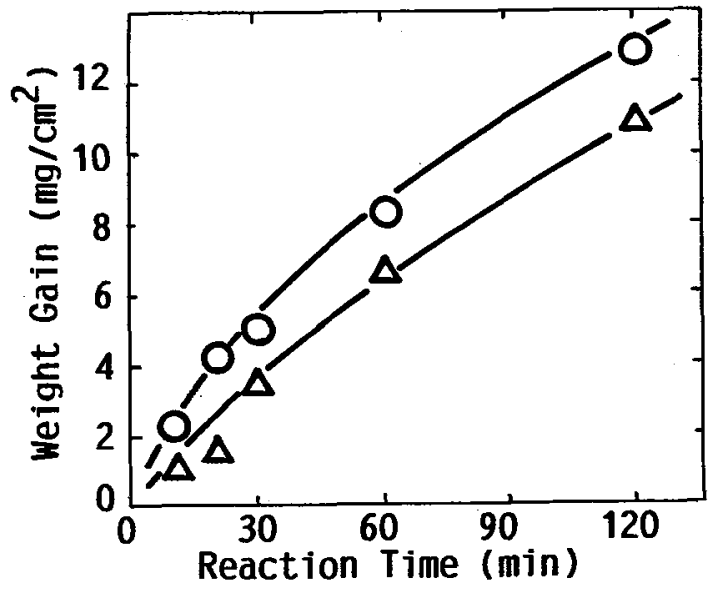

Fig.7. effect of reaction time on the weight gain of the deposits.

Reaction temperature $=1100^{\circ} \mathrm{C}$, reaction time $=30 \mathrm{~min}, \mathrm{CH}_{3} \mathrm{SiC1}$ gas flow rate=0.24 cc/s. ( $\triangle)$ : Without irradiation by $\mathrm{D}_{2}$ lamp, $(\mathrm{O})$ : with irradiation. (O) and $(\triangle): \beta-\mathrm{SiC}$ single phase. 